\title{
Informal Workers and the Politics of Working-class Transformation in the Americas
}

\author{
Ruth Felder, Ontario Tech University, Canada \\ Viviana Patroni, York University, Canada
}

Latin America is a region of great diversity, difficult to describe in general terms. Yet the one trend that characterises the entire region is the very unequal distribution of income and wealth and, with it, high levels of poverty. Inequality is an indelible mark upon which most countries in the region trace their modern history (Gootenberg and Reygadas, 2010). It is widely accepted that improving the conditions under which workers join urban and rural labour markets is central not only in overcoming poverty, but also in improving the distribution of income (Berry, 2013; Ocampo, 2014; Maurizio, Beccaria and Monsalvo, 2021). It follows, then, that the economic challenges most Latin Americans have experienced over the last thirty to forty years are closely connected to the economic and political obstacles workers have encountered in their attempts to defend the quality of their jobs and the jobs themselves. No phenomenon reflects this problem more clearly than the growing magnitude and diversity of forms of precarity and informality that have come to define the lived experiences of most workers in the region.

In this Special Issue of the Global Labour Journal we place work at the centre of Latin America's predicaments over income distribution and poverty, and we situate workers as key agents in the search for more equitable alternatives. The articles in the collection examine the multiple forms of precarious and informal labour, paying special attention to the interaction between the structural changes that account for the intensification of informality and precarity since the 1980s, the policies and institutional arrangements that respond to these structural changes, and the forms of collective action through which precarious and informal workers attempt to make their voices heard in the search for alternatives. Contributions to this Special Issue also invite reflections upon both the implications of informality and precarity for working-class identities and collective action and the challenges that the most vulnerable in our society confront in their daily lives.

We understand informality and precarity as multifaceted, complex and variegated phenomena. Both terms have been used to characterise a diversity of work situations that deviate from standard employment. Historically, informality referred to a sector of salaried and self-employed workers in microenterprises, domestic work and family work that was beyond state regulation (Hussmanns, 2004; Munck, 2013). This understanding of informality has gradually expanded to include not only the characteristics of enterprises but also the nature of labour relations, calling attention to the existence of informal employment in the formal sector of the economy (Chen, 2007; Busso and Pérez, 2010; De la Garza and Neffa, 2010; Breman and Van der Linden, 2014; De la Garza, 2017; Bromley and Wilson, 2018).

Precarity is a broader concept that captures the deteriorating working conditions affecting both formal and informal workers. Informality denotes one, in some cases extreme, form of precarity, though it is certainly not the only one. Precarious labour is usually defined in terms of what it lacks: a recognisable site of production, labour security, living wages, labour rights, union representation, etc. This way of defining precarious labour speaks to the difficulty in finding a common denominator for a broad diversity of situations that make people's working and living 
conditions precarious, including self-subsistence activities, housework, sweatshop labour in production chains, waged relations disguised as self-employment, microenterprises, family work, etc. This diversity is compounded by the evidence of porous frontiers between formal and informal/precarious work or "precarising formality" that challenges the dichotomy between standard and precarious employment and poses dilemmas for policymaking (De Oliveira, 2003; Fundación SOL, 2015; De la Garza, 2017; Munck, 2020; Durán and Narbona, this issue).

The expanding diversity of working experiences has also presented itself as a momentous challenge to working-class organising and to the understanding of work itself. A critical aspect of informal workers' demands has been to gain recognition as workers in the full sense of the term. Conceptually, a way to move beyond the seemingly insurmountable disparity of situations which characterise the working class as an overarching category is to focus on "the imperative to earn a living" that results from the situation of dispossession of workers in capitalism (Denning, 2010: 80). From this perspective, this imperative, and not the existence of wages or formal labour contracts, defines who is a worker and allows for reflection on the conditions that account for a growing diversity of work experiences, their structural and institutional underpinnings and their political manifestations and implications.

Writing during a time of a worldwide crisis brings a special pathos to our discussion. The health and economic dislocations unleashed by the COVID-19 pandemic have been particularly harsh for Latin America, a region that presently confronts its worst economic and social crisis in 120 years, with a fall in regional GDP of 7.7 per cent for 2020 (ECLAC, 2021: 13). As can only be imagined, the drastic reduction in economic activity has had negative implications for employment and thus also for poverty and inequality. While the COVID-19 pandemic has in some ways made the plight of large segments of the working class in the region more transparent, it is doubtful that it has enabled struggles for better working conditions. After a fleeting moment of recognition of the relevance of "essential workers" and their poor working conditions, most eyes seem placed once again on the promise of a prompt economic recovery. Yet, as the papers in the collection remind us, it is the existing patterns of economic growth which are responsible for the displacement, marginalisation and exploitation that shape the precarious existence of large segments of the region's population.

Our main objectives in this introduction are two-fold. First, we seek to provide some general background about informality and precarity as they have evolved in Latin America, both in terms of theoretical debates and also as essential components of workers' lived experiences. To this end, in the section below, we discuss employment in the context of the region's development trajectory. In the third section, we follow the conversation with some data on the momentous transformation of labour markets in the region since the 1980s. Our second goal is to suggest the ways in which this background informs and connects the various articles in the Special Issue as they explore the multiple manifestations of informality and precarity. This is the subject of the fourth and final section of this introduction.

\section{Modernisation, Informality and the Crisis of Development in Latin America}

Informality has long been the focus of a distinctive body of social research in Latin America and has figured prominently as an essential conversation within the broader debate on development in the region. Within this literature, a major focus of concern was the persistent weight of traditional low-productivity sectors in the economy where a high portion of the population toiled. Essential to some of the "modernising" views prevalent by the mid-twentieth century, the "backwardness" 
of these traditional sectors could be gauged by the incomplete nature of modernisation, both in terms of its scope and the preparedness of all citizens to become participants in the modern economy. Accordingly, the challenge was to find how to integrate workers in low-productivity sectors into the dynamic sectors of the economy, where productivity gains and the cycle of expanded growth could generate stable work and rising wages for new generations of workers. But the problem proved quite stubborn, becoming even more striking as industrialisation, along with its promise of great economic efficiencies and employment generation, advanced decisively in many countries in the region. By the late 1960s, modernisation theory, as a device for both understanding and transforming the conditions under which large segments of the population lived, had lost its lustre. Some of the most emblematic Latin American challenges to it were the writings of the Economic Commission for Latin America and the Caribbean (ECLAC) and what later came to be known as the Dependency School, which called attention to the dislocations that development brought to the region (Prebisch, 1950; Cardoso and Faletto, 1979; Marini, 1991).

As evidence of modernisation's shortcomings, students of the region pointed to the existence of a large "marginal mass" that was a product and an expression of the contours of dependent and monopolist capitalist development (Nun, [1969] 2001; Quijano, 1971; De Oliveira, 2003). "Marginality" had entered the social science lexicon of the region through the examination of the growth of marginal and precarious urban settlements (asentamientos marginales) and their inhabitants (poblacion marginal), a malaise that was due to the transition to modernity that Latin America was undergoing then and for which modernisation itself was expected to be the cure. Marginality then denominated the experience of the unemployed, precariously employed, large numbers of rural migrants arriving in urban centres - all of them in the search of new "modern" livelihoods but temporarily unable to find work. Alternatively, Argentinean sociologist José Nun suggested that the enduring poverty and marginality of these sectors could only be understood when embedded within capitalist social relations, particularly as they were being shaped in the context of Latin America's dependent, combined and unequal development (Nun, [1969] 2001).

Nun revisited Marx's understanding of the labour reserve army to argue that one of the key outcomes of capitalist development in its monopoly stage was the generation not only of a reserve army of the unemployed, but also an additional pool of labour that remained for the most part chronically unemployed. The concept was controversial because of its proposition that this marginal mass was not necessarily functional for capitalist accumulation because it was not absorbed through the wage relation into production or through consumption. While a thorough examination of the debate that the notion of marginal mass elicited is beyond our scope here, it bears mentioning that it brought attention to critical issues that remain central to the analysis of informality and precarity today. These include the difficulties with ascertaining the basis for the functional role of the informal sector in capitalist accumulation, be it as producers of cheap commodities, as consumers, as contingent waged workers, as unpaid workers and providers of care, etc.

All these Latin American contributions challenging the prevailing views of modernisation of the post-war period preceded the turn to informality introduced by Keith Hart in the 1970s. For Hart, the urban labour force faced a dualist model of income opportunities based on the distinction between wage employment and self-employment, that is, between its incorporation into the formal economy and its subsistence in the informal sector (Coletto, 2010). In the 1970s, the International Labour Organization (ILO) promoted the study of the informal sector in contexts of modernisation and urbanisation in the countries of the South. By showing the connections between the growth of the informal sector and these processes, the ILO's studies undermined 
modernisation theses about the gradual and eventual incorporation of all workers into the formal labour market.

The ILO's turn to informality fostered a new wave of debates about labour in Latin America (Svampa, 2019). Theoretical enquiries about the centrality of work in processes of social transformation in the region became a central arena of debate in the tumultuous period leading up to the 1980s, in which continuous high levels of informality and under- and unemployment remained a reminder of development's limitations.

In the 1980s, in response to the acute economic crisis created by mounting foreign debt, Latin American governments implemented economic and institutional reforms and adopted austerity policies that promised to lead countries on the road to growth and higher levels of employment (Robinson, 2004; Gwynne and Kay, 2014). It was in this context that informality came to be seen as the result of excess regulation and bureaucracy rather than as an expression of the contradictory nature of development processes (Lora and Pagés, 1997; Sabatini and Farnsworth 2006). Hernando de Soto famously expressed this view in his arguments about dynamic entrepreneurs who opt out of the formal economy due to its ineffective and expensive regulation. The logical corollary of this formulation was the simplification of legal and bureaucratic systems in line with laissez-faire labour relations (De Soto, 1989; Biles, 2009). Critical for our analysis, the deregulation of labour markets disguised as pro-poor policy became an appealing approach to address the challenge of informality (Felder and Patroni, 2018b). But if the post-war modernisation agendas failed to fully solve the problem of informality and precarity, the structural economic reforms of the 1980s and 1990s proved disastrous.

As neo-liberalism advanced globally, it became clear that the growing significance of informality and, more generally, the precarisation of labour were not confined to the countries of the Global South but were global expressions of the internationalisation of the economy and the weakened protections that accompanied it. Informality and precarity were then conceptualised as permanent phenomena and features of modern capitalist development rather than as relics from traditional economies (Chen, 2007; Coletto, 2010). Moreover, an influential body of studies on informality focused on the connections between the informal and formal sectors, emphasising the role of the former as a provider of a range of goods and services essential for production in the latter (Portes and Hoffman, 2003). Within this framework, the fluidity in work trajectories connecting workers to the two sectors became more visible.

Changes in regulatory frameworks allowed legal contracts to incorporate characteristics that had previously defined informal employment, that is, temporary, poorly paid and unprotected work (Felder and Patroni, 2018a; Durán and Narbona, this issue). As Latin America demonstrates, it became evident that rather than being limited to low-productivity activities in the informal sector, informality has traversed the entire economy and encroached upon the conditions of formal work through the flexibilisation of formerly secure jobs (Hussmans, 2004; Jonakin, 2006; Marshall, 2007; Figari and Alves, 2009). While governments in the region introduced changes in labour regulations with the stated objective of fostering higher rates of employment, the combination of economic change and new forms of labour regulation in the 1980s and 1990s was particularly detrimental to Latin American workers. The impact of these changes and of the subsequent crisis of neoliberalism on workers' lives is the focus of the section below.

\section{Informality and Precarity in Latin America since the 1980s}

Staring in the 1980s the number of informal and precarious jobs increased and already high rates 
of informality and inequality rose further (Portes and Hoffman, 2003, Álvarez Leguizamón, 2005). By some estimates, 70 per cent of the jobs created during the 1990s could be characterised as informal (ILO, 2003). Working conditions also deteriorated, and real average wages for the working class stagnated or declined during the 1990s (Weeks, 1999; Marshall, 2000). In addition, many countries saw increasingly segmented outcomes for workers based on gender and ethnicity (Brachet Márquez, 2001; De Oliveira, 2011; ILO, 2012). The financial and social crises that befell the region throughout the 1990s and early 2000s exposed both the shortcomings of neo-liberal reforms and their social costs (Patroni, 2008; Perrontini-Hernández, Vázquez-Muñoz and Avendaño-Vargas, 2011; Teichman, 2012).

Although the region's economic performance improved in the 2000s and policies in some countries signalled a renewed concern with the region's most pressing social predicaments (Huber and Stephens, 2012; ILO, 2012), economic growth was uneven. Some countries experienced high GDP growth driven by various admixtures of macroeconomic policies, fiscal stimuli and high international commodity prices, which helped counter the worst effects of neo-liberal reform (Saad-Filho, Iannini and Molinari, 2007; ECLAC, 2013). In other countries that still followed austerity policies, GDP grew more modestly. In general terms, poverty and inequality fell between the mid-2000s and the mid-2010s due to economic growth and job creation, new market regulations and subsidies, and innovative social policies (Gasparini et al., 2011; Lustig, López-Calva and Ortiz-Juarez, 2013). Nonetheless, after 2014 rates of poverty and inequality reduction, the pace of job creation and rates of economic growth weakened significantly. Between 2014 and 2019, growth rates on average only reached 0.3 per cent (ECLAC, 2021). Against many expectations, informality remained high in most Latin American countries even during the years of fast economic growth (Gasparini and Tornarolli, 2009; Tornarolli et al., 2014. According to the ILO, in 2019 informality in the Americas reached 53.8 per cent of total employment (Mezzadri, 2020).

Given these conditions, informality and precarity have become objects of renewed academic and political interest. Notably, current debates on social reproduction have contributed novel ways of thinking about some of the daunting issues informal and precarious workers and their families confront. Historically, the concept of social reproduction provided a way of thinking about the role not only of waged workers in the reproduction of capital, but also the essential role of unwaged workers within the household and the broader community in ensuring the production of labour. Similar to the debate around the "marginal mass", a substantial body of literature on social reproduction was originally centred around reassessing the contours of what is usually understood as labour that produces value and that which does not (Federici, 2019). Our starting point is somewhat broader. Social reproduction allows us to conceptualise the work and the resources required to ensure the survival, if not the wellbeing, of individuals, their families and communities. The state, the household, capital and civil society all have varying degrees of responsibility to provide some of the material and institutional bases that make social reproduction possible (Katz, 2001). Understood in this way, conversations about social reproduction are essential in thinking about informality since, as the discussion in this issue will show, the growing uncertainties and precarities in labour markets have also resulted in a crisis of social reproduction (Dinerstein and Pitts, 2018). While states withdrew services that were central for the reproduction of the labour force, the void has not always led to the commodification or privatisation of social reproduction as many proponents and some critics of neo-liberalism expected. On the contrary, as more people have become affected by poverty and informality, in some cases their efforts to ensure social reproduction strengthened collective approaches.

The articles in this Special Issue address precarious and informal workers' struggles around 
social reproduction, the conditions that determine their demands, their allies and the political resources workers bring to the process. In this regard, the notion of "territory" acquires a particular political significance. As Winders and Smith (2019: 872) suggest and Cielo and López Canelas show in their contribution to this issue, "social reproduction ... is a profoundly spatial phenomenon". The implications of the environmental crisis, land grabs, displacement and armed conflicts have had a devastating impact on the ability of individuals, their families and communities to ensure their reproduction and have further deteriorated the conditions that waged and unwaged workers encounter in labour markets. Moreover, as the physical, symbolic and political links to the community's territory are undermined by accumulation, so is their capacity to organise, either to protect their livelihoods against further encroachment from capital or to demand from the state the resources needed to ensure social reproduction. But spatiality and territory are also central in understanding the responses to the crisis of social reproduction in communities where the reconfiguration of the world of work has eroded the traditional ideological and physical distance between household and workplace. Initiatives undertaken by organisations like Argentina's Confederation of Popular Economy Workers (CTEP) to ensure the provision of basic needs for community members are a case in point (Bascuas et al., this issue). In this case, organising around the reproduction needs of communities expanded the political repertoire and potential for organisation of informal workers.

Lastly, it is important to note that central to the discussion of reproduction in Latin America is the role of domestic workers, who perform a large amount of paid reproductive work. Although there have been improvements in their recognition as essential workers, that has not been enough to provide the institutional protection required to address the conditions under which they work. As Manzano, Krein and Abílio mention in their contribution to this issue, while informal workers in Brazil benefitted substantially from policies geared to their formalisation, domestic workers remained marginal to the improvements. Thus, although the overall rate of informality fell by 14 per cent in Brazil for the 2003-2014 period, the figure was only 5 per cent for domestic workers (Manzano et al., this issue). Importantly, in some countries of the region domestic workers have managed to accomplish significant organisational gains, notwithstanding the major structural obstacles they face. This prompted the development of a growing body of literature assessing the factors that might facilitate their organisation as well as efforts to develop further intersectoral and international comparative studies (McBride and Tilly, 2021).

Through the case studies in this Special Issue, we expect to show the relevance of these debates in the study of informality and precarity in Latin America today. In this way, we also hope to contribute to fostering a better understanding of both the problem and the responses workers are forging through their struggles.

The section that follows draws upon the common understandings about the world of work we share as collaborators, and presents a summary of the articles through which we suggest a way of connecting the multiple realities of informalities the authors present.

\section{This Special Issue}

The works and debates considered above have contributed substantially to a better understanding of the dynamics of informality, its diversity and the political challenges people encounter in organising. Nonetheless, there are gaps in the literature on specific aspects of informality and precarity, and especially on their historical and political contours in specific countries and regions. As a group of researchers, we agreed it was worthwhile to revisit changes in the world of work over 
the last thirty years, bringing a more holistic perspective to bear in the development of our articles. We met at York University in Toronto, Canada, in May 2019 to share our work and to consider how the experience of informality and precarity has been reflected in debates about patterns of growth and job creation, the definition of work, the relationship between workers and the state, and forms of collective action by those not usually included in traditional trade unions. The meeting also led to a productive conversation about the meaning of precarity in the reproduction of everyday life, the vulnerabilities it generates, the many trajectories that lead people into the uncertainty and fragility precarity implies, and the strategies these people develop to deal with what amounts to a crisis of social reproduction. It was from these exchanges at the workshop that the idea for a special issue emerged.

Our research on the various forms of informality and precarity shares some key premises about the world of work as the expression of three interrelated facets. The first facet corresponds to the ways in which economic production is organised, which includes a consideration of specific strategies of accumulation and their adaptation to economic cycles. Our overall approach to the study of informality and precarity considers how the integration of national economies into the international flow of capital and trade impacts domestic and transnational labour markets (Leiva, 2011). It is also critical in our view to assess how various forms of organising production and work within the formal and informal sectors integrate with existing patterns of production and distribution.

The second facet relates to the nature of political conflict and negotiation. Contributions in this Special Issue are concerned with the conditions that promote or hinder practices, initiatives and forms of collective action that seek to bring about progressive change. They also pay attention to the way in which worker organisations have evolved in recent years. The study of the action of workers and labour movements allows us to reflect on the constellation of forces that might make more inclusive forms of development viable while assessing the role that worker organisations and other social actors play in the determination and transformation of state policies and, to some extent, on current patterns of growth (Schneider, 2009; De la Garza and Neffa, 2010).

The third facet refers to state intervention - understood as state policies, regulations and assistance - and the factors that shape and condition it (De la Garza, 2012; Huber and Stephens, 2012). This includes the capacity of the state both to extend and to condition social protection, and to regulate economic activity and labour markets to affect the creation and the quality of jobs (World Bank, 2012).

With these three facets as the general backdrop for our approach to the study of work and workers, the articles in this issue call attention to particular aspects of precarity in the context of the case studies they analyse. Gonzalo Durán and Karina Narbona take the case of Chile to highlight the deep transformation of formality itself over the last four decades. They propose the concept of "precarising formality" to bring to the fore the increasingly limited significance of commonly used concepts like formality and informality to fully account for the shape of labour markets in a country like Chile, which has been touted as a successful case of economic liberalisation. While much has been said about the country's high levels of formal employment (ILO, 2012; Bensusán, 2016), much remains hidden in the discussion unless the nature of formality and the way in which data on labour markets are gathered and interpreted are scrutinised. Thus, the authors argue, not only has a considerable portion of the Chilean working class remained informal, but those with formal work have faced increasingly precarious conditions (Durán and Narbona, this issue). Jobs are precarious because they fail to ensure the "sustainability and reproduction of the labour force" (Durán and Narbona, this issue), even if workers enjoy the 
privilege of formal employment. Chile's trajectory provides an excellent opportunity to explore the relationship among sustained rates of economic growth, the alleviation of poverty and the entrenchment of precarity as a feature of formal labour markets. In other words, the case of Chile might be taken as evidence that economic growth and "market friendly" development might very well lead to expanding formality for workers, but it does so at the cost of hollowing out the significance of formal employment itself.

Informality, precarity and precarising formality have become mounting hurdles for the ability of Chilean workers to struggle for the protection and expansion of their rights. These structural obstacles complicate the already debilitating legacies of the long and brutal authoritarian military dictatorship in Chile (1973-1990) that so deeply conditioned the responses of the working class to weakening systems of social and labour protection. Nonetheless, Durán and Narbona highlight some novel experiments in workers' organising that demonstrate the multiple ways in which collective action continues to reassert the promise of progressive change.

If one of the critical features in the case of Chile has been the endurance of institutional mechanisms that weaken workers' capacity to organise effectively, the article on Brazil by Marcelo Manzano, José Dari Krein and Ludmila Abílio highlights the possibilities that more receptive state policy can have on the ability of workers to improve their position within labour markets (Manzano et al., this issue; Baltar, Souen and De Souza Campos, 2017). To be sure, similar trends about precarising formality exist in Brazil. Nonetheless, between 2003 and 2014 state policies supported rising levels of formality. In this period the Brazilian economy grew considerably, and it was against this backdrop that state action appeared to have been more decisive in the extension of labour rights and improved working conditions. These changes also increased the structural and institutional power of unions, and thus their actions and organising potential were critical to the more inclusive transformation of labour markets.

However, if the intervention of the state can have this positive effect, the opposite is also true. After the right-wing turn in Brazilian politics in 2016, state policy promoted various forms of precarisation under the guise of employment promotion. As happened in the past, though, and against the logic of orthodox thinking, employment did not increase. The result was the rise once again of informality, a reality that, as the authors remind us, "produces and reproduces the intersecting structural inequalities in Brazilian society across gender, race and class" (Manzano et al., this issue).

To fully assess the implications of informalisation for Brazilian workers, the authors address the expanding presence of what has increasingly become known as "uberisation". This is a particularly disruptive form of organising the labour process whereby companies transfer most of the risks connected to profit-making to workers while at the same time depriving them of any social protection or rights. The authors remind us that although this form of informalisation is facilitated by new technologies, growing business monopolisation and already downgraded working conditions in labour markets are no less important. Finally, uberisation demarcates one more form of appropriation of the work of those who must ensure their reproduction by struggling to make a living among formal jobs that hardly afford any protection, other forms of employment that deny their right to be recognised as workers, and sporadic access to social assistance programmes. It is this "peripheral way of life" that characterises the experiences of large and ever-expanding segments of the working class in Brazil.

Social assistance programmes have become an essential reality for large segments of the working class in contemporary Latin America. Partly as the legacy of neo-liberalism in the region that so negatively affected incomes and working conditions, partly as the result of development 
regimes in the new century that have not been able to provide a way out of these conundrums, by 2012 almost one-fifth of the population in the region relied on social assistance (Svampa, 2019). Thus, social assistance programmes have become one of the main connections between precarious workers and the state. These programmes have transformed the nature of political action and the contours of working-class identities in ways that are critical for understanding not only informality and precarity but also working-class organising in the region. This is the phenomenon that Maisa Bascuas, Ruth Felder, Ana Logiudice and Viviana Patroni explore in their article on Argentina. Their focus is the origins and political significance of an organisation representing informal workers in Argentina, the Confederation of Popular Economy Workers (CTEP). Considerable attention has been paid in the specialised literature to the way in which social assistance programmes can become instruments to control the political development of organisations like CTEP, or the way in which organisations of informal workers have managed to use some of the resources of and connections to the state to grow and increase their political influence (Freytes Frey and Cross, 2005; Garay, 2007). While both approaches offer some insights into very complex dynamics, the authors suggest that there is considerably more involved in CTEP's political goals. Its key strategy, to surpass the confines of social policy and to seek more autonomy from the state, has also been crucial for its actions. Central to this strategy has been the struggle to gain status as a union and thus to have recognition of its work as socially important and of its members as productive workers. While these struggles have not always led to victories, they speak of a new way of organising informal workers and of thinking about work and the working class.

The discussion on Argentina allows for an appreciation of some of the factors that might facilitate the organisation of informal workers and the alliances they forge as they seek to overcome the most ominous consequences of their precarity. However, some informal workers confront considerably less auspicious conditions in their attempt to respond to the circumstances that force them into situations of extreme vulnerability. The complex life trajectories of those most affected by capitalist accumulation in Bolivia and Ecuador are at the core of Cristina Cielo and Elizabeth López Canelas' contribution to this issue. Looking through a feminist lens and following critical works in the field of extractivism (Mezzadra and Nielson, 2017; Gago, 2019) and reproductive work (Mezzadri, 2019), the authors explore the mechanisms of appropriation both of women's reproductive and informal work and of the very territories where women and their communities exist. The article highlights the experience of women in two locations. The first is in the Cerro Rico de Potosí, Bolivia, where silver mining has been a central economic activity since the colonial conquest of the region in the early 1500s. From then on, indigenous women's work has been essential for the survival of families and thus also to accumulation. The other location is the city of Esmeraldas in Ecuador where the oil refinery and the port became major sites of the petroleum industry since its expansion in the mid-1970s. In Esmeraldas, Afro-Ecuadorian women have borne the brunt of the ecological transformation brought about by petroleum extraction and the displacement it involves. Both territories share their vital role in the development and maintenance of extractive wealth, yet their populations are among the poorest in their own countries. Thus, while reliance on extractive industries for export has been justified in terms of the financial resources it makes available for public investment in the social infrastructure of the country, the true cost of the development alternative for large segments of the population becomes painfully evident.

It is in this context that the authors bring to light the role of gendered and racialised labour as essential components of extractive economic activities. Women's unpaid labour in reproduction and care and their underpaid informal work make possible both the viability of extractive activities 
and workers' survival. The notion of "territory" figures prominently in the analysis as it is used to indicate the way in which activities that have been so environmentally harmful have generated new challenges not only for social reproduction but also for the viability of informal activities upon which women must rely. Beyond the appropriation of these women's unpaid or underpaid labour, extractive activities "consume" the territories upon which the survival of communities hinge, uprooting and forcing them to reinvent livelihoods under more exacting conditions. This added dimension to the precarious lives people endure is further compounded by the impacts of territorial appropriation and environmental depletion on people's sense of identity, belonging and community. As the authors point out, the outcome is the undermining of their ability to mobilise in defence of their rights. These are, then, workers who are confronting not only vanishing spaces of survival but who are also increasingly isolated as political actors. In short, precarity becomes the defining condition for individuals and their communities.

Uprooting, displacement and deepening precarity are also central in understanding the realities of millions of Central American workers who must leave their communities and countries in search of employment elsewhere. Regrettably, as Abelardo Morales-Gamboa discusses in his contribution to this issue, the precarity that conditions the lives of Central American workers within their countries accompanies them in their journeys to the two main countries of destination for migrants in the region, the United States and Costa Rica. The vulnerabilities migrants confront as they leave their communities and embark on their journey, in what the author defines as high-risk or survival migration, form the core of his analysis. This transit not only compounds vulnerabilities, but also shapes the conditions of reception for these migrants in the countries of destination. To conceptualise the flows of Central American migrants, Morales-Gamboa proposes the notion of "corridors", a construct that provides a window into the circumstances migrants confront as they move along diverse geographic and social fields in their attempt to reach the countries of destination. Moreover, if the negation of basic rights is at the centre of the motivation to leave, migratory corridors accentuate vulnerabilities as they become the conduits for the negation of further rights. As the author states, “the cheapening of migrants' labour resulting from the devaluation of rights starts before this labour force enters the direct circuits of the relation between capital and labour in the destination country". In other words, to understand the full scope of the informality and precarity from which workers seek escape but which they most often re-encounter in labour markets elsewhere, it is necessary to grasp that the corridors they traverse to reach their destinations serve to reproduce the vulnerabilities that curtail options and cheapen their labour.

Workers are rendered vulnerable by the actions and inactions of states in the region, and in the case of the northern corridor to the United States, also by the activities of criminal groups that so callously exploit the vulnerabilities of migrants as the border between the US and Mexico becomes more impenetrable. The analysis of these corridors allows the author to unpack the meaning of informality and precarity in ways that provide new insights into the legal, environmental, social and economic factors that very often make leaving the migrants' places of origin a necessity of life but limit their options to accepting further informality and precarity as a condition of life. What emerges from the article then is a complex, multiscalar, transnational perspective of migratory systems and flows that both institutionally and socially ensure the production and reproduction of informality.

All in all, the articles engage in a dialogue that brings together issues pertaining to precarious and informal labour that have usually been studied separately, namely, enquiries about the structural conditions that account for the old and new forms of labour informality and precarity, the multiple forms that precarisation has taken in the wake of the neo-liberal restructuring of the economies of 
the region, and the problems that the growing heterogeneity of the working class pose for the intervention of the state and for workers' collective action. The articles are connected by a view of the complex interaction of factors that account for informal and precarious labour and by the acknowledgment of the need to historicise and politicise precarity. Beyond a doubt, the structural transformation in the pattern of capital accumulation has reshaped labour markets and labour relations but precarity is not a mere epiphenomenon of this structural change. Rather it is the historical outcome of the ways in which the changing balance of power among social forces translates into institutional arrangements and forms of collective action. This historical and political view of the problems allows us to acknowledge precarisation as an open-ended process whose evolution and transformation cannot be separated from the agency of precarious and informal workers. It manifests itself in survival strategies, forms of organising, relations of negotiation and conflict with the state and, no less important, in the desire and strength with which the different sections of the working class are able to overcome structural inequalities through their political action.

\section{References}

Álvarez Leguizamón, S. (2005) Trabajo y producción de la pobreza en Latinoamérica y el Caribe: estructuras, discursos $y$ actores. Buenos Aires: Consejo Latinoamericano de Ciencias Sociales (CLACSO).

Baltar, P.E, J.A. Souen and G.C. de Souza Campos (2017) Emprego e distribuição da renda. Working Paper No. 298, Instituto de Economia. Campinas. Brazil: Universidade de Campinas. https://www.eco.unicamp .br/images/arquivos/artigos/3527/TD298.pdf (accessed 2 April 2021).

Bensusán, G. (2016) Nuevas tendencias en el empleo: retos y opciones para las regulaciones y politicas del mercado de trabajo. Santiago: CEPAL.

Berry, A. (2013) Inequality, Poverty, and Employment: What We Know. Papers in Political Economy, 47: 1-28. http://interventionseconomiques.revues.org/1867 (accessed 3 October 2015).

Biles, J. (2009) Informal Work in Latin America. Geography Compass, 3(1): 214-236.

Brachet Márquez, V. (2001) Entre polis y mercado: el análisis sociológico de las grandes transformaciones políticas y laborales en América Latina. Mexico City: El Colegio de México, Centro de Estudios Sociológicos.

Breman, J. and M. van der Linden (2014) Informalizing the Economy: The Return of the Social Question at a Global Level. Development and Change, 45(5): 920-940.

Busso, M. and P. Pérez (eds.) (2010) La corrosión del trabajo: Estudios sobre informalidad y precariedad laboral. Buenos Aires: Miño y Dávila.

Bromley, R. and T.D. Wilson (2018) Introduction: The Urban Informal Economy Revisited. Latin American Perspectives, 45(1): 4-23.

Cardoso, F.H. and E. Faletto (1979) Dependency and Development in Latin America. Berkeley, CA: University of California Press.

Chen, M. (2007) Rethinking the Informal Economy: Linkages with the Formal Economy and the Formal Regulatory Environment. DESA Working Paper N. 46. https://www.un.org/esa/desa/papers/2007/wp46 2007.pdf (accessed 2 May 2020).

Coletto, D. (2010) The Informal Economy and Employment in Brazil. New York: Palgrave-Macmillan.

De la Garza, E. (2012) Informality, Organization, and Collective Action. Paper presented at the workshop "Poverty, Inequality and Economic Insecurity in Latin America: Deciphering the Political Economy of Precarious Employment”. York University, Toronto, May 2012. 
De la Garza, E. (2017) Crítica del concepto de informalidad y la propuesta del trabajo no clásico. Trabajo, $9(14): 51-70$.

De la Garza, E. and J. Neffa (eds.) (2010) Trabajo y modelos productivos en América Latina: Argentina, Brasil, Colombia, México, y Venezuela luego de las crisis del modelo de desarrollo neoliberal. Buenos Aires: Consejo Latinoamericano de Ciencias Sociales (CLACSO).

De Oliveira, F. (2003) Crítica à razão dualista/O ornitorrinco. São Paulo: Boitempo.

De Oliveira, S.M. (2011) Anuário das mulheres brasileiras. São Paulo: Departamento Intersindical de Estatística e Estudos Socioeconômicos (DIEESE).

De Soto, H. (1989) El otro sendero: La revolución invisible en el tercer mundo. New York: Harper \& Row.

Denning, M. (2010) Wageless Life. New Left Review, 66: 79-97.

Dinerstein, A. and F. Pitts (2018) From Post-Work to Post Capitalism? Discussing the Basic Income and Struggles for Alternative Forms of Social Reproduction. Journal of Labor and Society, 21(4): 471-491.

Economic Commission for Latin America and the Caribbean (ECLAC) (2013) Preliminary Overview of the Economies of Latin America and the Caribbean 2012. Santiago, Chile: United Nations.

Economic Commission for Latin America and the Caribbean (ECLAC) (2021) Preliminary Overview of the Economies of Latin America and the Caribbean, 2020 (LC/PUB.2020/17-P/Rev.1). Santiago, Chile: United Nations.

Federici, S. (2019) Social Reproduction Theory. Radical Philosophy, 2(4): 55-57.

Felder, R. and V. Patroni (2018a) Precarious Work in Recession and Growth: A New Structural Feature of Labor Markets in Argentina? Radical Review of Political Economics, 50(1): 44-65.

Felder, R. and V. Patroni (2018b) Organizing the Unorganisable: The Case of Popular Economy Workers in Argentina. Journal of Labour and Society, 21(2): 121-136.

Figari, C. and G. Alves (eds.) (2009) La precarización del trabajo en América Latina: Perspectivas del capitalismo global. São Paulo: Editorial Praxis.

Freytes Frey, A. and C. Cross (2005) Políticas sociales y tradiciones ideológicas en la constitución de los movimientos de trabajadores desocupados. Paper presented at the 7 th Congreso Nacional de Estudios del Trabajo. Asociación Argentina de Especialistas en Estudios del Trabajo. Buenos Aires, August 2005. https://aset.org.ar/congresos/7/12021.pdf (accessed 10 July 2021).

Fundación SOL (2015) Ser justos es lo primero. La crisis de los trabajadores dominicanos bajo el actual modelo económico. Santo Domingo: Fundación Juan Bosch.

Gago, V. (2019) La potencia feminista: o el deseo de cambiarlo todo. Madrid: Traficantes de Sueños.

Garay, C. (2007) Social Policy and Collective Action: Unemployed Workers, Community Associations, and Protest in Argentina. Politics \& Society, 35(2): 301-328.

Gasparini, L., G. Cruces, L. Tornarolli and D. Mejía (2011). Recent Trends in Income Inequality in Latin America. Economía, 11(2): 147-201.

Gasparini, L. and L. Tornarolli (2009). Labor Informality in Latin America and the Caribbean: Patterns and Trends from Household Survey Microdata. Desarrollo y Sociedad, 14(63): 13-80.

Gootenberg P. and L. Reygadas (eds.) (2010) Indelible Inequalities in Latin America: Insights from History, Politics and Culture. Durham, NC and London: Duke University Press.

Gwynne, R.C. and C. Kay (2014) Latin America Transformed: Globalization and Modernity. Second edition. London and New York: Routledge.

Huber, E. and J. Stephens (2012) Democracy and the Left: Social Policy and Inequality in Latin America. Chicago: University of Chicago Press.

Hussmans, R. (2004) Measuring the Informal Economy: From Employment in the Informal Sector to Informal Employment. Working Paper No. 53. Geneva: International Labour Organization. 
International Labour Organization (ILO) (2003) 2003 Labour Overview: Latin America and the Caribbean. Ithaca, NY: Regional Office for Latin America and the Caribbean, International Labour Organization.

International Labour Organization (ILO) (2012) World of Work Report 2012: Better Jobs for a Better Economy. Geneva: International Institute for Labour Studies, International Labour Organization.

Jonakin, J. (2006) Cycling between Vice and Virtue: Assessing the Informal Sector's Awkward Role under Neoliberal Reform. Review of International Political Economy, 13(2): 290-312.

Katz, C. (2001) Vagabond Capitalism and the Necessity of Social Reproduction. Antipode, 33: 709-728.

Leiva, F. (2011). Analyzing the Impact of Globalization on Latin America: Five Strategies Derived from Political Economy. In Globalization, Social Justice and the Healing Professions, edited by K. Briar-Lawson and B. Holt. Albany: SUNY Press.

Lora, E. and C. Pagés (1997) La legislación laboral en el proceso de reformas estructurales de América Latina y el Caribe. Working Paper No. 343. New York: Inter-American Development Bank.

Lustig, N., L.F. López-Calva and E. Ortiz-Juarez (2013) Declining Inequality in Latin America in the 2000s: The Cases of Argentina, Brazi, and Mexico. World Development, 44: 129-141.

Marini, R.M. (1991) Dialéctica de la dependencia. Mexico City: Era.

Marshall, A. (2000) Labor Market Regulation, Wages and Workers’ Behavior. Latin America in the 1990 s. Paper delivered at the XXII International Congress of the Latin American Studies Association, March 16-18, Miami, FL.

Marshall, A. (2007) Explaining Non-compliance with Labour Legislation in Latin America: A Cross-country Analysis. Discussion paper 184/2007. Geneva: International Institute for Labour Studies, International Labour Organization.

Maurizio, R., L. Beccaria and A. Monsalvo (2021) Labour Formalization and Inequality: The Distributive Impact of Labour Formalization in Latin America since 2000. Development and Change, 0(0): 1-49. DOI: 10.1111/dech.12653

McBride, J. and C. Tilly, with R. Agarwala, J.J. Chun, G. Rojas, B. Scully, S. Swider, and N. Theodore (2021) Organizing Informal Workers to Win: Lessons from Informal Domestic and Construction Workers in Six Countries. Los Angeles, CA: UCLA Institute for Research on Labor and Employment.

Mezzadra, S. and B. Neilson (2017) On the Multiple Frontiers of Extraction: Excavating Contemporary Capitalism. Cultural Studies, 31(2-3): 185-204.

Mezzadri, A. (2020) The Informal Labours of Social Reproduction. Global Labour Journal, 11(2), $156-163$.

Mezzadri, A. (2019) On the Value of Social Reproduction: Informal Labour, the Majority World and the Need for Inclusive Theories and Politics. Radical Philosophy, 2(4): 33-41.

Munck, R. (2013) The Precariat: A View from the South. Third World Quarterly, 34(5): 747-762.

Munck, R. (2020) Work and Capitalist Globalization: Beyond Dualist Reason. Review of Radical Political Economics, 52(3): 371-386.

Nun, J. ([1969] 2001) Marginalidad y exclusión social Buenos Aires: Fondo de Cultura Económica.

Ocampo, J.A. (2014) Latin American Structuralism and Production Development Strategies. In Transforming Economies: Making Industrial Policy Work for Growth, Jobs and Development, edited by J.M. Salazar-Xirinachs, I. Nübler and R. Kozul-Wright. Geneva: ILO.

Patroni, V. (2008) Economic Restructuring, Neoliberalism, and the Working Class. In Capital, Power, and Inequality in Latin America and the Caribbean, edited by R. Harris and J. Nef. Lanham, MD: Rowman and Littlefield.

Perrotini- Hernández, I., J.A. Vázquez-Muñoz and B.L. Avendaño-Vargas (2011) Beyond the Washington Consensus: The Quest for an Alternative Development Paradigm for Latin America. In Market Liberalism, Growth, and Economic Development in Latin America, edited by G. Angeles-Castro, I. PerrotiniHernández and H. Ríos-Bolívar. London: Routledge. 
Portes, A. and K. Hoffman (2003) Latin American Class Structures: Their Composition and Change during the Neoliberal Era. Latin American Research Review, 38(1): 41-82.

Prebisch, R. (1950) The Economic Development of Latin America and its Principal Problems. UN document no. E/CN.12/89/Rev.1. Lake Success, N.Y.: United Nations.

Quijano, A. (1971) Polo marginal de la economía y mano de obra marginada. Lima: Universidad Católica.

Robinson, W. (2004) A Theory of Global Capitalism. Production, Class, and State in a Transnational World. Baltimore, MD: Johns Hopkins University.

Saad-Filho, A., F. Iannini, and E. Molinari (2007) Neoliberalism, Democracy and Economic Policy in Latin America. In Political Economy of Latin America: Recent Economic Performance, edited by P. Arestis and M. Sawyer. London: Palgrave Macmillan.

Sabatini, C. and E. Farnsworth (2006) A "Left Turn" in Latin America? The Urgent Need for Labor Law Reform. Journal of Democracy, 17(4): 50-64.

Schneider, B.R. (2009) Hierarchical Market Economies and Varieties of Capitalism in Latin America. Journal of Latin American Studies, 41(3): 553-575.

Svampa, M. (2019) El aporte de José Nun y la larga vida de la marginalidad. In José Nun y las ciencias sociales: Aportes que perduran, edited by M. Heredia, S. Pereyra and M. Svampa. Buenos Aires: Biblos.

Teichman, J. (2012) Social Forces and States: Poverty and Distributional Outcomes in South Korea, Chile and Mexico. Stanford, CA: Stanford University Press.

Tornarolli, L., D. Battistón, L. Gasparini and P. Gluzmann (2014) Exploring Trends in Labor Informality in Latin America, 1990-2010. Working paper No. 159. La Plata: CEDLAS University of La Plata.

Weeks, J. (1999) Wages, Employment and Workers' Rights in Latin America, 1970-98. International Labour Review, 138: 151.

Winders, J. and B.E. Smith (2019) Social Reproduction and Capitalist Production: A Genealogy of Dominant Imaginaries. Progress in Human Geography, 43(5): 871-889.

World Bank (2012) The World Development Report 2013: Jobs. Washington, DC: The World Bank.

\section{ACKNOWLEDGEMENTS}

As co-editors of this Special Issue, we would like to thank the anonymous reviewers of the individual contributions for their comments and suggestions. We would also like to thank the Editorial Board of the Global Labour Journal, very specially Maria Lorena Cook, for the support they extended to us during the various stages in the preparation of this Issue. Our appreciation also to Karin Pampallis for her attention to detail and excellent editorial work, and to Shana Shubs who so ably assisted us with the translation of some of the original articles.

\section{BIOGRAPHICAL NOTES}

RUTH FELDER is an assistant teaching professor in the Political Science Program, Faculty of Social Science and Humanities at Ontario Tech University. She is a research fellow of the Institute for the Study of Latin American and the Caribbean of the University of Buenos Aires. Her research focuses on the political economy of development with a focus on Argentina and with attention to class relations underlying the role of the state and policies. [Email: ruth.felder@ontariotechu.ca]

VIVIANA PATRONI is an associate professor in the Department of Social Science at York University. She is a research fellow with the Global Labour Research Centre (GLRC) and the Centre for 
Research on Latin America and the Caribbean (CERLAC), both at York University. Her research focuses on the political economy of Latin America, the transformation of the world of work in this region since the 1980s, the centrality of labour struggles in shaping patterns of development and the transformation of labour markets in Argentina since the 1990s. [Email: vpatroni@yorku.ca] 